\title{
Reduction of $\boldsymbol{\beta}$-Ketoalkyl 2-(1-Dimethylaminoethyl)phenyl Sulfoxides: Synthesis of (-)-Matsutakeol
}

\author{
Makoto Shimazaki, Norie Ichihara, Mikiko Goto, and Akihiro Oнta* \\ Tokyo College of Pharmacy, Horinouchi, Hachioji 192-03, Japan. Received March 9, 1992
}

Five $\beta$-ketoalkyl 2-(1-dimethylaminoethyl)phenyl sulfoxides $(2 a-e)$ were prepared by lithiation at the $\alpha$-methyl hydrogen to the sulfoxide group of $N, N$-dimethyl-1-(2-methylsulfinylphenyl)ethylamine (1), followed by condensation with esters. The reduction of $2 a-e$ gave two kinds of $\beta$-hydroxysulfoxides $(3 a-e$ and $4 a-e)$, whose structures were determined by transforming 4 a to naturally occurring ( - -matsutakeol. The results on the diastereoselectivity of this reduction and the ${ }^{1} \mathrm{H}$-NMR spectral behavior of the $\alpha$-hydrogens to the sulfoxide group were different from those found in the case of reduction of $\beta$-ketoalkyl tolyl sulfoxides.

Keywords asymmetric synthesis; asymmetric reduction; matsutakeol; chiral sulfoxide; $\beta$-ketosulfoxide; $\beta$-hydroxysulfoxide

Recently, we have reported the preparation ${ }^{1)}$ of (-)$N, N$-dimethyl-1-(2-methylsulfinylphenyl)ethylamine (1) from a cheap, readily available starting material, $(+)-1-$ phenylethylamine, and the asymmetric synthesis ${ }^{2)}$ of a component of Greek tobacco from (+)-1. The results of our previous experiments show that $\mathbf{1}$ can be utilized effectively in the field of asymmetric synthesis. We now present the synthesis of (-)-matsutakeol, ${ }^{3)}$ a flavor compound of the mushroom Tricholoma matsutake, via the reduction of (-)- $N, N$-dimethyl-1-[2-(2-oxoheptylsulfinyl)phenyl] ethylamine (2a) prepared from $(-)-\mathbf{1}$. The synthetic route is shown in Chart 1 . Further, four $\beta$-ketosulfoxides $(2 \mathbf{b}-\mathbf{e})$ were also obtained by the same procedure and the structures of their reduced products were determined by<smiles>CCCCCC(=O)C[S](O)c1ccccc1C(C)C</smiles>

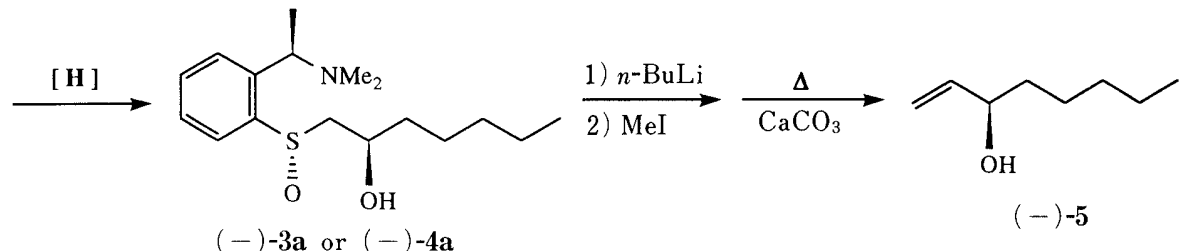

Chart 1

TABLE I. Spectral Data for $(-)-\mathbf{2 a}-\mathbf{e}$

\begin{tabular}{|c|c|c|c|c|c|c|c|}
\hline $\begin{array}{l}\text { Compd. } \\
\text { No. }\end{array}$ & $\mathrm{R}$ & $\begin{array}{l}\text { Molecular } \\
\text { formula }\end{array}$ & $\begin{array}{l}\mathrm{mp} \\
\left({ }^{\circ} \mathrm{C}\right)\end{array}$ & $\begin{array}{c}{[\alpha]_{\mathrm{D}}^{24 e)}} \\
\left({ }^{\circ}\right)\end{array}$ & $\begin{array}{l}\text { Yield }^{f)} \\
(\%)\end{array}$ & ${ }^{1} \mathrm{H}-\mathrm{NMR}\left(\mathrm{CDCl}_{3} / \mathrm{TMS}\right) \delta(\mathrm{ppm}), J(\mathrm{~Hz})$ & $\begin{array}{l}\text { MS (DCI) } \\
\quad(\mathrm{m} / \mathrm{z})\end{array}$ \\
\hline $2 a$ & $n-\mathrm{C}_{5} \mathrm{H}_{11}$ & $\mathrm{C}_{17} \mathrm{H}_{27} \mathrm{NO}_{2} \mathrm{~S}^{a)}$ & $\mathrm{Oil}^{c)}$ & -178 & 65 & $\begin{array}{l}0.89(3 \mathrm{H}, \mathrm{t}, J=6.9), 1.25-1.35(6 \mathrm{H}, \mathrm{m}), 1.47(3 \mathrm{H}, \mathrm{d}, J=6.9) \\
2.16(6 \mathrm{H}, \mathrm{s}), 2.63(2 \mathrm{H}, \mathrm{t}, J=7.0), 3.39(1 \mathrm{H}, \mathrm{q}, J=6.9), 3.59 \\
(1 \mathrm{H}, \mathrm{d}, J=13.2), 3.88(1 \mathrm{H}, \mathrm{d}, J=13.2), 7.28-7.52(3 \mathrm{H}, \mathrm{m}) \\
8.12(1 \mathrm{H}, \mathrm{d}, J=7.5)\end{array}$ & $310(\mathrm{M}+1)$ \\
\hline $2 b$ & $\mathrm{Ph}$ & $\mathrm{C}_{18} \mathrm{H}_{21} \mathrm{NO}_{2} \mathrm{~S}^{a)}$ & $\mathrm{Oil}^{\mathrm{c})}$ & -226 & 68 & $\begin{array}{l}1.50(3 \mathrm{H}, \mathrm{d}, J=7.0), 2.18(6 \mathrm{H}, \mathrm{s}), 3.42(1 \mathrm{H}, \mathrm{q}, J=7.0), 4.17 \\
(1 \mathrm{H}, \mathrm{d}, J=12.0), 4.50(1 \mathrm{H}, \mathrm{d}, J=12.0), 7.28-7.65(6 \mathrm{H}, \mathrm{m}) \\
8.03(2 \mathrm{H}, \mathrm{m}), 8.16(1 \mathrm{H}, \mathrm{d}, J=7.5)\end{array}$ & $316(\mathrm{M}+1)$ \\
\hline $2 c$ & iso- $\mathrm{C}_{3} \mathrm{H}_{7}$ & $\mathrm{C}_{15} \mathrm{H}_{23} \mathrm{NO}_{2} \mathrm{~S}^{b)}$ & $77-78^{d)}$ & -191 & 66 & $\begin{array}{l}1.11(3 \mathrm{H}, \mathrm{d}, J=6.9), 1.16(3 \mathrm{H}, \mathrm{d}, J=6.9), 1.46(3 \mathrm{H}, \mathrm{d}, \\
J=6.9), 2.16(6 \mathrm{H}, \mathrm{s}), 2.76-2.86(1 \mathrm{H}, \mathrm{m}), 3.40(1 \mathrm{H}, \mathrm{q}, \\
J=6.9), 3.68(1 \mathrm{H}, \mathrm{d}, J=13.8), 3.97(1 \mathrm{H}, \mathrm{d}, J=13.8), 7.30 \\
(1 \mathrm{H}, \mathrm{d}, J=7.5), 7.43(1 \mathrm{H}, \mathrm{t}, J=7.5), 7.48(1 \mathrm{H}, \mathrm{t}, J=7.5), 8.15 \\
(1 \mathrm{H}, \mathrm{d}, J=7.5)\end{array}$ & $282(\mathrm{M}+1)$ \\
\hline $2 d$ & cyclo- $\mathrm{C}_{6} \mathrm{H}_{11}$ & $\mathrm{C}_{18} \mathrm{H}_{27} \mathrm{NO}_{2} \mathrm{~S}^{b)}$ & $89-90^{d)}$ & -232 & 60 & $\begin{array}{l}1.30(4 \mathrm{H}, \mathrm{m}), \mathrm{I} .46(1 \mathrm{H}, \mathrm{d}, J=6.8), 1.64-2.00(6 \mathrm{H}, \mathrm{m}), 2.16 \\
(6 \mathrm{H}, \mathrm{s}), 2.54(1 \mathrm{H}, \mathrm{m}), 3.40(1 \mathrm{H}, \mathrm{q}, J=6.8), 3.67(1 \mathrm{H}, \mathrm{d} \\
J=14.5), 3.95(1 \mathrm{H}, \mathrm{d}, J=14.5), 7.30(1 \mathrm{H}, \mathrm{d}, J=7.6), 7.40 \\
(1 \mathrm{H}, \mathrm{t}, J=7.6), 7.48(1 \mathrm{H}, \mathrm{t}, J=7.6), 8.13(1 \mathrm{H}, \mathrm{d}, J=7.6)\end{array}$ & $322(\mathrm{M}+1)$ \\
\hline $2 e$ & Benzyl & $\mathrm{C}_{19} \mathrm{H}_{23} \mathrm{NO}_{2} \mathrm{~S}^{b)}$ & $78-79^{d)}$ & -180 & 66 & $\begin{array}{l}1.42(3 \mathrm{H}, \mathrm{d}, J=6.9), 2.07(6 \mathrm{H}, \mathrm{s}), 3.33(1 \mathrm{H}, \mathrm{q}, J=6.9), 3.63 \\
(1 \mathrm{H}, \mathrm{d}, J=13.8), 3.88(1 \mathrm{H}, \mathrm{d}, J=12.0), 3.95(1 \mathrm{H}, \mathrm{d}, J=13.8) \\
3.98(1 \mathrm{H}, \mathrm{d}, J=12.0), 7.18-7.38(6 \mathrm{H}, \mathrm{m}), 7.41(1 \mathrm{H}, \mathrm{t} \\
J=7.6), 7.48(1 \mathrm{H}, \mathrm{t}, J=7.6), 8.13(1 \mathrm{H}, \mathrm{d}, J=7.6)\end{array}$ & $330(M+1)$ \\
\hline
\end{tabular}

a) Molecular formula obtained from the high-resolution mass spectra: $m / z \pm 3.0 \times 10^{-3}$. b) Molecular formula obtained by elemental analyses: $\mathrm{C}, \mathrm{H}, \mathrm{N}+0.30 \%$. c) Viscous oils which were too unstable to be distilled. d) Melting points measured without correction after the recrystallization from $n$-hexane. $e$ ) Optical rotation measured in $\mathrm{CHCl}_{3}(c=1.0)$. f) Yields refer to pure isolated compounds. 
${ }^{1} \mathrm{H}-\mathrm{NMR}$ spectral comparison with $\mathbf{4 a}$, which could be converted to ( - )-matsutakeol (5).

Many papers on procedures for the reduction of $\beta$ -<smiles>CC(C)c1ccccc1S(C)=O</smiles><smiles>[R]C(=O)C[S](O)c1ccccc1C(C)N(C)C</smiles>

Chart 2

TABLE II. Reduction of $\mathbf{2 b}$ with Various Reagents

\begin{tabular}{llcccc}
\hline \hline Reductant & Solvent & $\begin{array}{c}\text { Temp. } \\
\left({ }^{\circ} \mathrm{C}\right)\end{array}$ & $\begin{array}{c}\text { Time } \\
(\mathrm{h})\end{array}$ & $\begin{array}{c}\text { Yield } \\
(\%)^{a)}\end{array}$ & $\mathbf{3 b / 4 \mathbf { b } ^ { b ) }}$ \\
\hline $\mathrm{NaBH}_{4}$ & $\mathrm{MeOH}$ & Reflux & 1 & 96 & $34 / 66$ \\
$\mathrm{NaBH}_{4}$ & $\mathrm{MeOH}$ & r.t. & 15 & 71 & $31 / 69$ \\
$\mathrm{LiAlH}_{4}$ & THF & r.t. & 15 & 55 & $33 / 67$ \\
$\mathrm{DIBAH}^{c)}$ & THF & r.t. & 15 & 8 & - \\
$\mathrm{Zn}\left(\mathrm{BH}_{4}\right)_{2}$ & THF & r.t. & 15 & 1 & - \\
\hline
\end{tabular}

a) Yields as the mixture of $\mathbf{3 b}$ and $\mathbf{4 b}$. b) Ratio of $\mathbf{3 b} / \mathbf{4 b}$ determined by ${ }^{1} \mathrm{H}-\mathrm{NMR}$ $(\delta 1.45$ of $3 \mathbf{b} / \delta 1.47$ of $4 \mathbf{b})$. $\quad c)$ DIBAH $=$ diisobutylaluminum hydride $(1.0 \mathrm{M}$ in cyclohexane). r.t. $=$ room temperature. ketosulfoxides have been presented but there is no example of a $\beta$-ketoalkyl aryl sulfoxide, such as $\mathbf{2 a}$, substituted by a chiral functional group at the ortho-position of the aromatic ring. Solladie et $a l^{4)}$ synthesized $\beta$-ketoalkyl tolyl sulfoxides and reported the ratio of their reduction products, two kinds of $\beta$-hydroxysulfoxides. We prepared $(-) \mathbf{2} \mathbf{a}-\mathbf{e}$ by the lithiation of $(-) \mathbf{- 1}$ followed by reaction with various esters, and the results are shown in Table I.

An examination of reducing agents was carried out

TABLE III. Reduction of $\mathbf{2 a - e}$ with $\mathrm{NaBH}_{4}$

\begin{tabular}{ccccc}
\hline Compd. & $\mathrm{R}$ & Yield $(\%)^{a)}$ & $\mathbf{3} / \mathbf{4}^{b)}$ & HPLC $^{c)}$ \\
\hline 2a & $n-\mathrm{C}_{5} \mathrm{H}_{11}$ & 99 & $41 / 59$ & $\mathrm{~A}$ \\
$\mathbf{2 b}$ & $\mathrm{Ph}$ & 96 & $34 / 66$ & $\mathrm{~B}$ \\
$\mathbf{2 c}$ & ${\text { iso- }{ }_{3} \mathrm{H}_{7}}_{\text {2d }}^{\text {2d }}$ & 99 & $39 / 61$ & $\mathrm{~A}$ \\
$\mathbf{2 e}$ & cyclo- ${ }_{6} \mathrm{H}_{11}$ & 97 & $45 / 55$ & $\mathrm{C}$ \\
& Benzyl & 98 & $40 / 60$ & $\mathrm{C}$ \\
\hline
\end{tabular}

a) Yields as the mixture of $3 \mathbf{a}-\mathbf{e}$ and $\mathbf{4 a}-\mathbf{e}$. b) Ratio of $3 \mathbf{a}-\mathbf{e} / \mathbf{4 a}-\mathbf{e}$ determined by ${ }^{1} \mathrm{H}$-NMR. The following peaks were used for this purpose: $\delta 1.43 / \delta 1.48$ for $3 \mathbf{a} / \mathbf{4 a}$, $\delta 1.45 / \delta 1.47$ for $\mathbf{3 b} / \mathbf{4 b}, \delta 1.44 / \delta 1.49$ for $\mathbf{3 c} / \mathbf{4 c}, \delta 1.44 / \delta 1.49$ for $\mathbf{3 d} / \mathbf{4 d}, \delta 1.20 / \delta 1.37$ for $3 \mathrm{e} / 4 \mathrm{e}$. c) The solvent systems for preparative $\mathrm{HPLC}$ were: $\mathrm{A}, \mathrm{MeOH}(55) / \mathrm{H}_{2} \mathrm{O}$ (40) $/ 25 \% \mathrm{NH}_{4} \mathrm{OH}(5) ; \mathrm{B}, \mathrm{MeOH}(90) / \mathrm{H}_{2} \mathrm{O}(10)$; $\mathrm{C}$, a suitable solvent could not be found.<smiles>CC(C)c1ccccc1[S](O)CC(=O)c1ccccc1</smiles><smiles>CC(C)c1ccccc1[Hg](O)C[C@H](O)c1ccccc1</smiles>

Chart 3

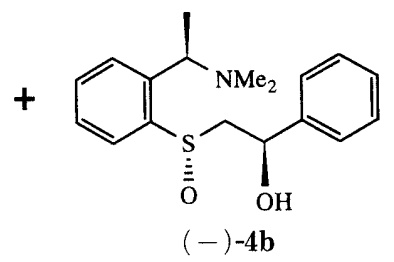

TABLE IV. Spectral Data for $(-)-\mathbf{3 a}-\mathbf{c}$ and $(-)-\mathbf{4 a}-\mathbf{c}$

\begin{tabular}{|c|c|c|c|c|c|c|}
\hline $\begin{array}{l}\text { Compd. } \\
\text { No., }{ }^{a)}\end{array}$ & $\mathbf{R}$ & $\begin{array}{l}\text { Molecular } \\
\text { formula }^{b)}\end{array}$ & $\begin{array}{c}{[\alpha]_{\mathrm{D}}^{24 c)}} \\
\left({ }^{\circ}\right)\end{array}$ & $\begin{array}{l}\text { Yield }^{d)} \\
(\%)\end{array}$ & ${ }^{1} \mathrm{H}-\mathrm{NMR}\left(\mathrm{CDCl}_{3} / \mathrm{TMS}\right) \delta(\mathrm{ppm}), J(\mathrm{~Hz})$ & $\begin{array}{c}\text { MS (DCI) } \\
\quad(m / z)\end{array}$ \\
\hline $3 \mathbf{a}$ & $n-\mathrm{C}_{5} \mathrm{H}_{11}$ & $\mathrm{C}_{17} \mathrm{H}_{29} \mathrm{NO}_{2} \mathrm{~S}$ & -41 & 36 & $\begin{array}{l}0.89(3 \mathrm{H}, \mathrm{t}, J=6.9), 1.20-1.40(6 \mathrm{H}, \mathrm{m}), 1.43(3 \mathrm{H}, \mathrm{d}, J=6.9) \\
1.50-1.71(2 \mathrm{H}, \mathrm{t}, J=6.9), 2.15(6 \mathrm{H}, \mathrm{s}), 2.71(1 \mathrm{H}, \mathrm{dd}, J=2.0,13.5) \\
3.01(1 \mathrm{H}, \mathrm{dd}, J=10.0,13.2), 3.34(1 \mathrm{H}, \mathrm{q}, J=7.0), 4.14-4.24(1 \mathrm{H}, \\
\mathrm{m}), 7.35(1 \mathrm{H}, \mathrm{d}, J=7.5), 7.43(1 \mathrm{H}, \mathrm{t}, J=7.5), 7.50(1 \mathrm{H}, \mathrm{t}, J=7.5) \\
8.16(1 \mathrm{H}, \mathrm{d}, J=7.5)\end{array}$ & $312(M+1)$ \\
\hline $\mathbf{3 b}$ & $\mathrm{Ph}$ & $\mathrm{C}_{18} \mathrm{H}_{23} \mathrm{NO}_{2} \mathrm{~S}$ & -67 & 35 & $\begin{array}{l}1.45(3 \mathrm{H}, \mathrm{d}, J=7.0), 2.15(6 \mathrm{H}, \mathrm{s}), 2.86(1 \mathrm{H}, \mathrm{dd}, J=2.0,13.5), 3.33 \\
(1 \mathrm{H}, \mathrm{dd}, J=10.0,13.5), 3.38(1 \mathrm{H}, \mathrm{q}, J=7.0), 5.29(1 \mathrm{H}, \mathrm{dd}, J=2.0 \\
10.0), 7.28-7.38(6 \mathrm{H}, \mathrm{m}), 7.43(1 \mathrm{H}, \mathrm{t}, J=7.6), 7.52(1 \mathrm{H}, \mathrm{t}, J=7.6) \\
8.23(1 \mathrm{H}, \mathrm{d}, J=7.6)\end{array}$ & $318(M+1)$ \\
\hline $3 \mathbf{c}$ & iso- $\mathrm{C}_{3} \mathrm{H}_{7}$ & $\mathrm{C}_{15} \mathrm{H}_{25} \mathrm{NO}_{2} \mathrm{~S}$ & -49 & 35 & $\begin{array}{l}0.89(3 \mathrm{H}, \mathrm{d}, J=7.0), 0.90(3 \mathrm{H}, \mathrm{d}, J=6.9), 1.44(3 \mathrm{H}, \mathrm{d}, J=6.9) \\
1.70-1.85(1 \mathrm{H}, \mathrm{m}), 2.15(6 \mathrm{H}, \mathrm{s}), 2.70(1 \mathrm{H}, \mathrm{dd}, J=2.0,13.5), 3.09 \\
(1 \mathrm{H}, \mathrm{dd}, J=10.0,13.5), 3.34(1 \mathrm{H}, \mathrm{q}, J=6.9), 3.81-4.03(1 \mathrm{H}, \mathrm{dd} \\
J=2.0,10.0), 7.36(1 \mathrm{H}, \mathrm{d}, J=7.5), 7.45(1 \mathrm{H}, \mathrm{t}, J=7.5), 7.52(1 \mathrm{H}, \mathrm{t} \\
J=7.5), 8.16(1 \mathrm{H}, \mathrm{d}, J=7.5)\end{array}$ & $284(M+1)$ \\
\hline $4 a$ & $n-\mathrm{C}_{5} \mathrm{H}_{11}$ & $\mathrm{C}_{17} \mathrm{H}_{29} \mathrm{NO}_{2} \mathrm{~S}$ & -381 & 45 & $\begin{array}{l}0.89(3 \mathrm{H}, \mathrm{t}, J=6.9), 1.25-1.35(6 \mathrm{H}, \mathrm{m}), 1.48(3 \mathrm{H}, \mathrm{d}, J=6.9), \\
1.55-1.63(2 \mathrm{H}, \mathrm{t}, J=6.9), 2.16(6 \mathrm{H}, \mathrm{s}), 2.74(1 \mathrm{H}, \mathrm{dd}, J=10.0,13.5), \\
3.05(1 \mathrm{H}, \mathrm{dd}, J=2.0,13.2), 3.34(1 \mathrm{H}, \mathrm{q}, J=7.0), 4.16-4.27(1 \mathrm{H}, \mathrm{m}), \\
7.29(1 \mathrm{H}, \mathrm{d}, J=7.5), 7.41(1 \mathrm{H}, \mathrm{t}, J=7.5), 7.50(1 \mathrm{H}, \mathrm{t}, J=7.5), 8.15 \\
(1 \mathrm{H}, \mathrm{d}, J=7.5)\end{array}$ & $312(\mathrm{M}+1)$ \\
\hline $4 \mathbf{b}$ & $\mathrm{Ph}$ & $\mathrm{C}_{18} \mathrm{H}_{23} \mathrm{NO}_{2} \mathrm{~S}$ & -467 & 61 & $\begin{array}{l}1.47(3 \mathrm{H}, \mathrm{d}, J=7.0), 2.15(6 \mathrm{H}, \mathrm{s}), 2.98(1 \mathrm{H}, \mathrm{dd}, J=10.0,13.5), 3.21 \\
(1 \mathrm{H}, \mathrm{dd}, J=2.0,13.5), 3.34(1 \mathrm{H}, \mathrm{q}, J=7.0), 5.34(1 \mathrm{H}, \mathrm{dd}, J=2.0 \\
10.0), 7.28-7.42(6 \mathrm{H}, \mathrm{m}), 7.51(1 \mathrm{H}, \mathrm{t}, J=7.6), 8.19(1 \mathrm{H}, \mathrm{d}, J=7.6)\end{array}$ & $318(M+1)$ \\
\hline $4 c$ & iso- $\mathrm{C}_{3} \mathrm{H}_{7}$ & $\mathrm{C}_{15} \mathrm{H}_{25} \mathrm{NO}_{2} \mathrm{~S}$ & -401 & 50 & $\begin{array}{l}0.93(3 \mathrm{H}, \mathrm{d}, J=7.0), 0.94(3 \mathrm{H}, \mathrm{d}, J=6.9), 1.49(3 \mathrm{H}, \mathrm{d}, J=6.9), \\
1.70-1.85(1 \mathrm{H}, \mathrm{m}), 2.15(6 \mathrm{H}, \mathrm{s}), 2.69(1 \mathrm{H}, \mathrm{dd}, J=10.0,13.5), 3.10 \\
(1 \mathrm{H}, \mathrm{dd}, J=2.0,13.5), 3.34(1 \mathrm{H}, \mathrm{q}, J=6.9), 3.95-4.14(\mathrm{dd}, 1 \mathrm{H}, \\
J=2.0,10.0), 7.28(1 \mathrm{H}, \mathrm{d}, J=7.5), 7.41(1 \mathrm{H}, \mathrm{t}, J=7.5), 7.52(1 \mathrm{H}, \mathrm{t} \\
J=7.5), 8.16(1 \mathrm{H}, \mathrm{d}, J=7.5)\end{array}$ & $284(\mathrm{M}+1)$ \\
\hline
\end{tabular}

a) All products were viscous oils which are too unstable to be distilled. $b$ ) Molecular formula obtained from the high-resolution mass spectra: $m / z \pm 3.0 \times 10^{-3}$ c) Optical rotation measured in $\mathrm{CHCl}_{3}(c=1.0)$. d) Yields refer to pure isolated compounds. 


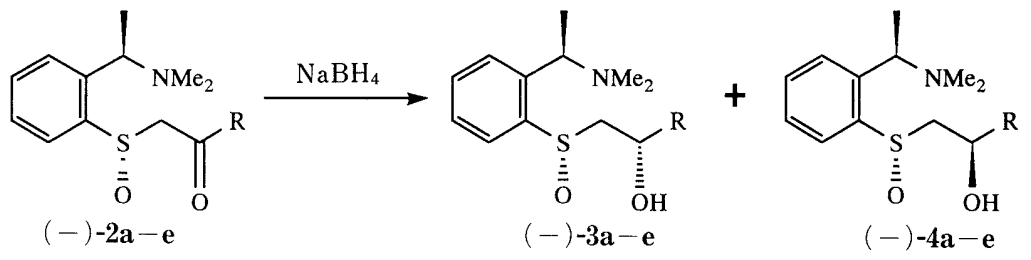

Chart 4
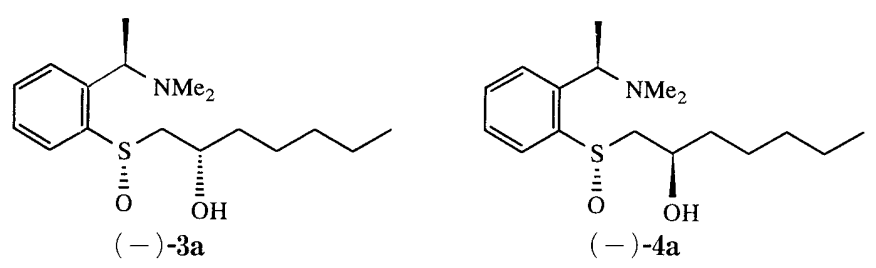

Fig. 1. Absolute Structures of (-)-3a and (-)-4a
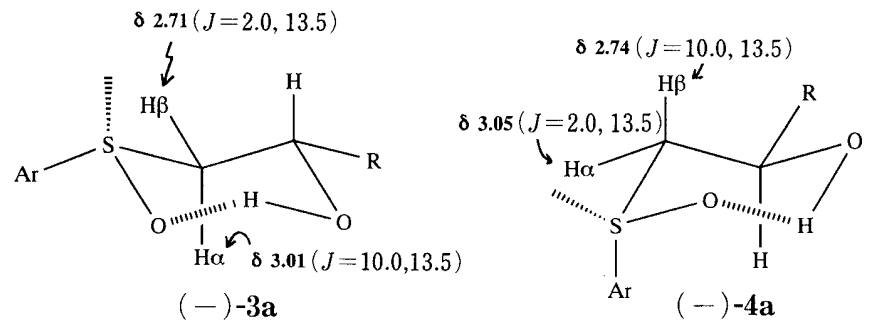

$[\mathrm{Ar}=2$-(1-dimethylaminoethyl) phenyl, $\mathrm{R}=$ pentyl $]$

Fig. 2. Chemical Shift and $J$ Values Observed in the ${ }^{1} \mathrm{H}-\mathrm{NMR}$ Spectra of $(-)-\mathbf{3 a}$ and $(-)-\mathbf{4 a}$

using $\mathbf{2 b}$ as the substrate and the ratio of the resulting two diastereomeric $(-)-\beta$-hydroxysulfoxides $(\mathbf{3 b} \text { and } \mathbf{4 b})^{5)}$ was determined by ${ }^{1} \mathrm{H}-\mathrm{NMR}$. So far as the chemical yield is concerned, sodium borohydride was the most suitable agent for this reduction, as shown in Table II. The purification of the products was accomplished by preparative HPLC with an octadecyl silica (ODS) column.

The results of the reduction of $\mathbf{2 a} \mathbf{a}$ with sodium borohydride and the spectral data of the resulting $\beta$ hydroxysulfoxides $(3 \mathbf{a}-\mathbf{e}$ and $\mathbf{4 a -}-\mathbf{e})$ are shown in Tables III and IV, respectively. Among the products, the separation of (-)-3d, e and (-)-4d, e could not be accomplished.

Takano et al. have already presented the asymmetric synthesis of naturally occurring (-)-matsutakeol (5) by pyrolysis of optically pure 2-phenylsulfinyl-3-octanol (6) prepared from $(R)$-epichlorohydrin. ${ }^{6)}$ Both (-)-3a and $(-)-\mathbf{4 a}$ are analogs of $\mathbf{6}$, and $\mathbf{4 a}$ was converted to naturally occurring 5 according to Takano et al. Accordingly, the absolute configurations of (-)-3a and (-)-4a are as shown in Fig. 1.

The chemical shift and $J$ values of the two $\alpha$-hydrogens to the SO group of $\mathbf{3 a}$ and $\mathbf{4 a}$ are shown in Fig. 2. One of the vicinal coupling constants is $2.0 \mathrm{~Hz}$ and the other one is $10.0 \mathrm{~Hz}$. The former corresponds to axial-equatorial coupling of the six-membered ring and the latter to axial-axial coupling. Both of $\mathbf{3 a}$ and $\mathbf{4 a}$ seem to have an intramolecular hydrogen bond between the oxygen atom of the SO group and the hydrogen atom of the $\mathrm{OH}$ group, and so the conformational structures of $\mathbf{3 a}$ and $\mathbf{4 a}$ were suggested to be as shown in Fig. 2. The structures of $\mathbf{3 b}, \mathbf{c}$ and $\mathbf{4 b}$, $\mathbf{c}$ were determined by the comparison of their ${ }^{1} \mathrm{H}-\mathrm{NMR}$ data with those for 3a and 4a. It was found that the ${ }^{1} \mathrm{H}$-NMR signal of the $\alpha$-hydrogen threo to the oxygen atom of the SO group was observed at lower field than that of the other $\alpha$-hydrogen regardless of the configuration around the $\beta$-carbon atom.

Though the reduction of $\mathbf{2 a}-\mathbf{e}$ mainly gave $\mathbf{4 a -}-\mathbf{e}$, as described previously, the major products obtained from $\beta$-ketoalkyl tolyl sulfoxides by Solladie et al. ${ }^{4)}$ were the compounds corresponding to $\mathbf{3 a}-\mathbf{e}$. Concerning the ${ }^{1} \mathrm{H}-$ NMR spectra of the diastereomeric isomers, the $\alpha$ hydrogen signal with the larger vicinal coupling constant appeared at lower field than that with the smaller one, presumably owing to the effect of the ortho-chiral group of $2 \mathbf{a}-\mathbf{e}$, though the details are unclear.

\section{Experimental}

Proton nuclear magnetic resonance $\left({ }^{1} \mathrm{H}-\mathrm{NMR}\right)$ spectra were recorded on a Brucker AM-400 in $\mathrm{CDCl}_{3}$ using tetramethylsilane (TMS) as the internal standard, and the following abbreviations are used; $s=$ singlet, $\mathrm{d}=$ doublet, $\mathrm{t}=$ triplet, $\mathrm{q}=$ quartet, $\mathrm{m}=$ multiplet. Mass spectra $(\mathrm{MS})$ and high-resolution mass spectra (HR-MS) were obtained using a Hitachi M-80B spectrometer. Optical rotations were measured with a JASCO DIP-360 in $\mathrm{CHCl}_{3}(c=1.0)$.

General Procedure for the Synthesis of (-)-N,N-Dimethyl-1-[2-(2oxoalkylsulfinyl)phenyl]ethylamines (2a-e) A solution of $(-)-1(2.11 \mathrm{~g}$, $10 \mathrm{mmol})^{1)}$ in dry tetrahydrofuran (THF) $(50 \mathrm{ml})$ was treated with $n$-butyllithium (1.6 M solution in $n$-hexane, $6.8 \mathrm{ml}, 11 \mathrm{mmol})$ at $-78^{\circ} \mathrm{C}$ under an argon atmosphere. The mixture was stirred for $15 \mathrm{~min}$ under the same conditions and methyl carboxylate $(15 \mathrm{mmol})$ was added to the resulting solution. The reaction mixture was stirred for $2 \mathrm{~h}$, then poured into $5 \% \mathrm{HCl}(300 \mathrm{ml})$, and the aqueous solution was washed with $\mathrm{Et}_{2} \mathrm{O}$ $(150 \mathrm{ml} \times 3)$, neutralized with $\mathrm{K}_{2} \mathrm{CO}_{3}$ and extracted with $\mathrm{Et}_{2} \mathrm{O}$. The solvent was removed by distillation and the residue was purified by silica gel column chromatography (Kieselgel 60, 240-400 mesh, 30 g) using a mixture of $n$-hexane (50)/AcOEt (50) as the developing solvent.

General Procedure for the Synthesis of $(-)-N, N$-Dimethyl-1-[2-(2hydroxyalkylsulfinyl)phenyl]ethylamines $(3 \mathrm{a}-\mathrm{e}$ and $4 \mathrm{a}-\mathrm{e})$ Sodium borohydride $(14.5 \mathrm{mg}, 0.38 \mathrm{mmol})$ was added to a solution of $(-)-2 \mathrm{a}-\mathbf{e}$ $(0.35 \mathrm{mmol})$ in $\mathrm{MeOH}(7 \mathrm{ml})$. The mixture was refluxed for $1 \mathrm{~h}$ and the solvent was removed in vacuo. The residue was dispersed in water $(10 \mathrm{ml})$ and the suspension was extracted with $\mathrm{Et}_{2} \mathrm{O}(10 \mathrm{ml} \times 3)$. The organic solution was dried over $\mathrm{Na}_{2} \mathrm{SO}_{4}$, then $\mathrm{Et}_{2} \mathrm{O}$ was removed by distillation and the residue was subjected to preparative HPLC with an ODS column. When the solvent listed in Table II was used as the developing solvent, $(-)-\mathbf{3 a}-\mathbf{c}$ was eluted first, and $(-)-\mathbf{4 a}-\mathbf{c}$ followed. However, the mixtures of $(-)-\mathbf{3 d}, \mathbf{e}$ and $(-)-4 d, e$ could not be separated from each other cleanly

Synthesis of (-)-Matsutakeol (5) from (-)-4a This experiment was carried out using (-)-4a $(155 \mathrm{mg}, 0.5 \mathrm{mmol})$ according to the reported procedure $^{6)}$ for the synthesis of (-)-matsutakeol from a diastereomeric mixture of 2-hydroxyheptylsulfinylbenzene. The ${ }^{1} \mathrm{H}-\mathrm{NMR}$ spectral data of the product coincided with those of naturally occurring $(-)-5$. Yield: $64 \% .[\alpha]_{\mathrm{D}}-9.2^{\circ}\left(\right.$ lit. $\left.\left.{ }^{6}\right)-8.8^{\circ}\right) .{ }^{1} \mathrm{H}-\mathrm{NMR} \delta: 0.85(3 \mathrm{H}, \mathrm{t}, J=7.0 \mathrm{~Hz})$, $1.15-1.48(9 \mathrm{H}, \mathrm{m}), 4.10(1 \mathrm{H}, \mathrm{m}), 5.09(1 \mathrm{H}, \mathrm{dd}, J=1.5,7.0 \mathrm{~Hz}), 5.19$ $(1 \mathrm{H}, \mathrm{dd}, J=1.5,17.4 \mathrm{~Hz}), 5.83(1 \mathrm{H}, \mathrm{dd}, J=7.0,17.4 \mathrm{~Hz})$.

\section{References and Notes}

1) M. Shimazaki, M. Takahashi, H. Komatsu, A. Ohta, K. Kajii, and Y. Kodama, Synthesis, 1992, 555. 
2) M. Shimazaki and A. Ohta, Synthesis, in press.

3) S. Murahashi, Sci. Pap. Inst. Phys. Chem. Res., 30, 263 (1936).

4) G. Solladie, C. Greck, G. Demailly, and A. S. Cavallo, Tetrahedron Lett., 23, 5047 (1982).

5) The main products were $4 \mathbf{a}-\mathbf{e}$. The retention times of $\mathbf{3 a}-\mathbf{c}$ were shorter than those of the corresponding $4 \mathbf{a}-\mathbf{c}$ on HPLC with an ODS column.

6) S. Takano, M. Yanase, M. Takahashi, and K. Ogasawara, Chem. Lett., 1987, 2017. 